\title{
ИССЛЕДОВАНИЕ СПЕКТРАЛЬНЫХ ХАРАКТЕРИСТИК ШУМА И ОЦЕНКА ЕГО ВЛИЯНИЯ НА ВОЗМОЖНОСТЬ РЕГИСТРАЦИИ СЕЙСМИЧЕСКИХ СОБЫТИЙ КАРЕЛЬСКОЙ СЕЙСМОЛОГИЧЕСКОЙ СЕТЬЮ
}

\author{
В. А. Мещерякова, А. А. Герасимова \\ Институт геологии КарНЦ РАН, г. Петрозаводск \\ Поступила в редакцию 1 февраля 2019 г.
}

\begin{abstract}
Аннотация: работа посвящена оценке влияния шума на сейсмическую запись, что необходимо для надежного выделения сейсмических событий различной силы и удалённости. Исследование возможности регистрации сейсмических событий Карельской сейсмологической сети основано на построение графиков спектральной плотности мощности шума (СПМ) относительно модельных кривых Петерсона. Для каждой сейсмической станции описаны суточные и сезонные различия шумовых спектров. Все компоненты сейсмических станций Карелии расположены в пределах модельных кривых Петерсона высокого и низкого уровня шума, за исключением горизонтальных компонент станции «Паанаярви», остальные станции соответствуют поставленным задачам сейсмического контроля территории Карелии. По графикам СПМ шума за год сейсмические станции распределены по возрастанию уровня шума: «Петрозаводск», «Питкяранта», «Костомукша».
\end{abstract}

Ключевые слова: сейсмология, сейсмические станщии, спектр плотности мощности шума, модели низкого и высокого шума, модели Петерсона.

\section{THE STUDY OF THE SPECTRAL CHARACTERISTICS OF NOISE AND THE ASSESSMENT OF ITS INFLUENCE ON THE POSSIBILITY OF RECORDING SEISMIC EVENTS BY THE KARELIAN SEISMOLOGICAL NETWORK}

\begin{abstract}
: the work is devoted to assessing the impact of noise on the seismic record, which is necessary for the reliable isolation of seismic events of varying strength and distance. The study of the possibility of recording seismic events of the Karelian seismological network is based on the construction of graphs of the power spectral density of the noise (PSD) relative for Peterson's model curves. Daily and seasonal differences of noise spectra are described for each seismic station. All components of the Karelian seismic stations are located within the Peterson model curves of high and low noise level, with the exception of the horizontal components of the PAAN station, other stations correspond to the tasks of seismic control of Karelia. According to the SPM noise charts for one year seismic stations are distributed by increasing noise level: "Petrozavodsk", "Pitkyaranta", "Kostomuksha".

Key words: seismology; seismic stations; spectrum of the noise power density; high- and low-noise models; Peterson's models.
\end{abstract}

Введение

Для изучения глубинного строения и сейсмического режима территории Карелии в 1999 г. основана региональная сейсмологическая сеть [1], которая на данный момент оснащена современной аппаратурой велосиметрами Guralp CMG-3ESP и CMG-6TD. Tpaдиционно сейсмологов интересовали крупные сейсмические события, а шум рассматривался как некоторая помеха, усложняющая обработку сейсмических колебаний от регулярных источников [2]. В настоящее время необходимо производить оценку влияния шума на запись с целью надёжного выделения сейсмических событий различной силы и удалённости. Наиболее информативной характеристикой шума яв- ляется его спектр [3]. Построение и анализ графиков спектра плотности мощности (СПМ) шума в данной работе является необходимым условием для исследования возможности регистрации сейсмических событий в районе установки станций Карельской сейсмологической сети, что и является целью данной работы.

Геологическая и геодинамическая характеристика исследуемых территорий

Территория республики Карелия расположена в пределах Фенноскандинавского щита, в структуре которого выделяются Карельский неоархейский кратон, Беломорский подвижный пояс и Свекофенская 
провинция [4].

Карельский кратон составляет ядро Фенноскандинавского щита и сложен, главным образом, архейскими гранитоидными, зеленокаменными и парагнейсовыми комплексами, менее распространены гранулитовые комплексы [4]. Беломорский подвижный пояс располагается с северо-востока от Карельского кратона и сложен преимущественно неоархейскими грани- тогнейсами [4], а Свекофенская провинция в исследуемом регионе представлена небольшой частью, которая именно в нашем регионе стыкуется с Карельским кратоном и представлена гранитогнейсами [5]. Горные породы и геотектоническая структура в месте установки станции представлены в табл.1. Географическое расположение сейсмических станций - на рис.1.

Таблица 1

Краткая геологическая и геотектоническая характеристика территорий установки сейсмических станций

\begin{tabular}{|c|c|c|}
\hline Станция & Геологические породы & Геотектоническая структура \\
\hline PTRZ (Петрозаводск) & $\begin{array}{c}\text { Пикриты, пикробазальты, базальты, туфы, туффиты, } \\
\text { туфоконгломераты [6] }\end{array}$ & Карельский кратон [4] \\
\hline PITK (Питкяранта) & $\begin{array}{c}\text { Лавы и туфы амфиболизированных базальтов, горизонты туфогенно- } \\
\text { карбонатных, арбонатных и кремнисто-карбонатных пород [7] }\end{array}$ & Свекофенская провинция [4] \\
\hline PAAN (Паанаярви) & Биотитовые гнейсы, гранито-гнейсы [8] & Карельский кратон [4] \\
\hline KOS6 (Костомукша) & $\begin{array}{c}\text { Углеродсодержащие сланцы, кислые эффузивы, магнетитовые } \\
\text { сланцы и кварциты [9] }\end{array}$ & Карельский кратон [4] \\
\hline
\end{tabular}

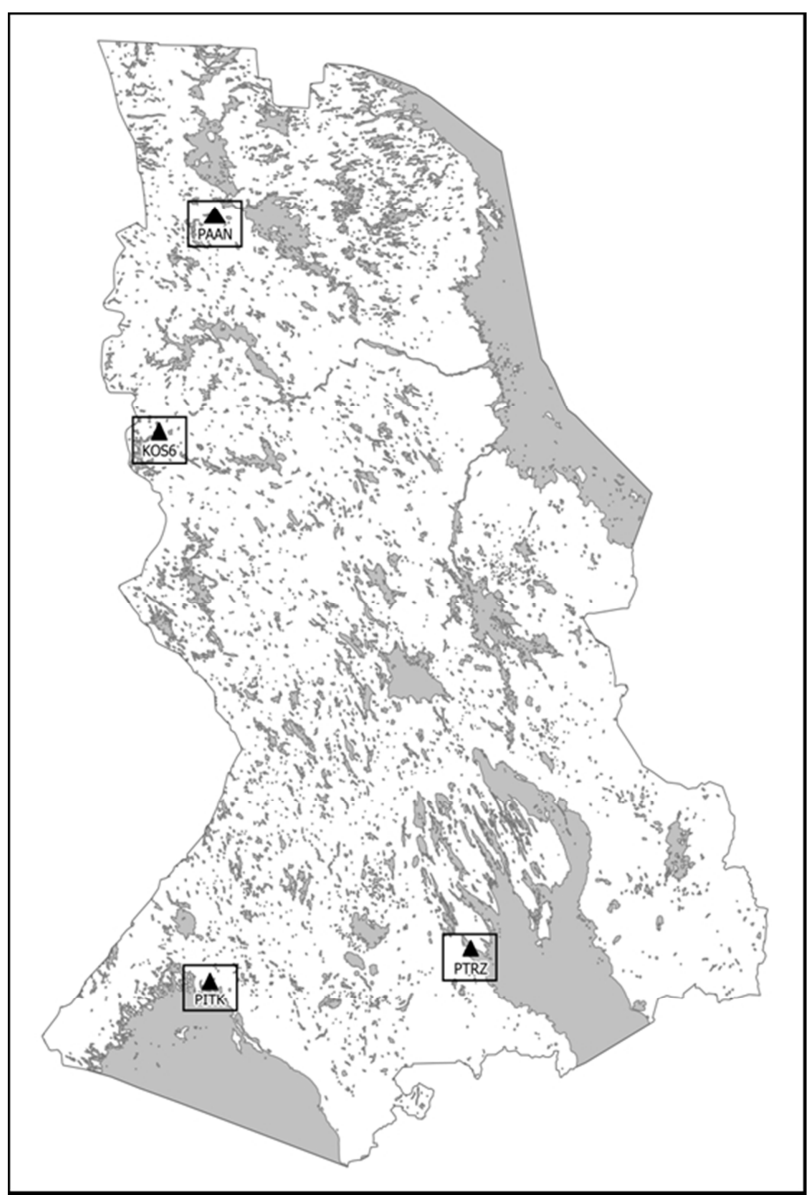

Рис. 1. Карта-схема расположения сейсмических станций Карельской сейсмологической сети.

\section{Материалы и методы}

С 2014 г. на территории Карелии действует сеть сейсмических станций на базе широкополосной аппаратуры - CMG-6TD и CMG-3ESP (АЦП - GSR 24). Станции PTRZ, PITK и PAAN установлены в специально оборудованных сейсмических павильонах на бетонные постаменты, имеющие контакт с коренными породами, a KOS6 - в цокольном этаже помещения.

Координаты расположения станций указаны в табл. 2 и на рис. 1 соответственно.

Основные данные используемой аппаратуры описаны в табл. 3 .

Регистрационные возможности установленной на сейсмических станциях аппаратуры, при полосовой фильтрации определённых частот, позволяют выделять телесейсмические землетрясения, а также события регионального и локального масштаба.

Основная функция сейсмической станции - получение данных, качество которых значительно возрастает при низких значениях уровня шума [10], поэтому именно он и является одним из основных параметров, определяющих вероятности обнаружения полезных сейсмических сигналов [3]. Для оценки уровня шума используют стандартные модели Петерсона (NLNM, NHNM низкого и высокого шума в записи станции), представляющие результат статистической обработки обширного массива данных 75 станций глобальной сейсмологической сети [11] и являющиеся эталонами уровня шума в окрестностях функционирования сейсмостанций.

Для анализа выбирались часовые отрезки записей без сейсмических событий отдельно за ночное время (22-23 ч GMT) и дневное время (4-5 ч GMT) для каждого сезона года. Спектры построены по выборкам, состоящим из 10 фрагментов записей.

Построение СПМ шума выполнено в программе PNP, разработанной сотрудниками КоФГС РАН. Алгоритм вычисления СПМ шума описан в [12].

\section{Полученные результаты}

На рисунках ниже приведены графики СПМ шума по вертикальным компонентам сейсмических станций Карельской сейсмологической сети. 
Таблица 2

Сейсмические станции на территории республики Карелия

\begin{tabular}{|c|c|c|c|c|c|}
\hline \multirow{2}{*}{ Станция } & \multirow{2}{*}{ Дата открытия } & \multicolumn{2}{|c|}{ Координаты } & $\mathrm{h}, \mathrm{m}$ \\
\cline { 5 - 6 } \cline { 4 - 5 } & & $\varphi^{\circ}, \mathrm{N}$ & $\lambda^{\circ}, \mathrm{E}$ & \\
\hline Название & Код & & $61^{\circ} 50^{\prime} 32.9^{\prime \prime}$ & $34^{\circ} 22^{\prime} 49^{\prime \prime}$ & 81 \\
\hline Петрозаводск & PTRZ & 20.01 .2013 & $61^{\circ} 40^{\prime} 13.7^{\prime \prime}$ & $31^{\circ} 15^{\prime} 57,6^{\prime \prime}$ & 104 \\
\hline Питкяранта & PITK & 03.06 .2014 & $65^{\circ} 45^{\prime} 38.88^{\prime \prime}$ & $31^{\circ} 4^{\prime} 11.64^{\prime \prime}$ & 166 \\
\hline Паанаярви & PAAN & 02.06 .2016 & $64^{\circ} 35^{\prime} 28.7^{\prime \prime}$ & $30^{\circ} 35^{\prime} 39^{\prime \prime}$ & 228 \\
\hline Костомукша & KOS6 & 19.06 .2014 & \multicolumn{2}{|c}{}
\end{tabular}

Таблица 3

Данные о ичифровых сейсмических станџиях ИГ КарНЦ РАН

\begin{tabular}{|c|c|c|c|c|c|c|}
\hline Код и местоположение станции & 目照 & 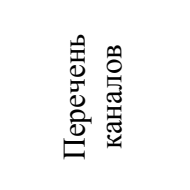 & 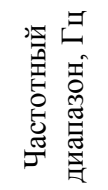 & 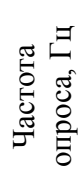 & 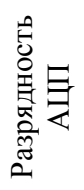 & 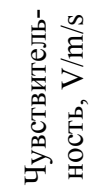 \\
\hline $\begin{array}{c}\text { PTRZ Ботанический Сад ПетрГУ, } \\
\text { г. Петрозаводск }\end{array}$ & $\begin{array}{l}\text { CMG-3ESP } \\
+ \text { GSR } 24\end{array}$ & $\mathrm{BH}(\mathrm{Z}, \mathrm{N}, \mathrm{E})$ & $120-50$ & 40 & 24 & $2 * 1000$ \\
\hline PITK д. Леппясилта, Питкярантский р-он & \multirow{3}{*}{ CMG-6TD } & \multirow{3}{*}{$\mathrm{MH}(\mathrm{Z}, \mathrm{N}, \mathrm{E})$} & \multirow{3}{*}{$30-100$} & \multirow{3}{*}{50} & \multirow{3}{*}{24} & \multirow{3}{*}{$2 * 1200$} \\
\hline KOS6 г. Костомукша & & & & & & \\
\hline PAAN Лоухский р-он & & & & & & \\
\hline
\end{tabular}

Сейсмическая станциия «Костомукша» KOS6

Кривые СПМ шума в ночное время в течение года от 1 с и выше практически не отличаются друг от друга, кроме весны, где наблюдается повышение уровня шума приблизительно на 5 Дб в промежутке частот 16-13 Гц (рис. 2a).

Аналогия в поведении кривых СПМ шума наблю- дается и днём во все сезоны, только весной прослеживается уже плавное уменьшение уровня шума до 4 Дб от дневных компонент остальных времен года в промежутке частот 14-10 Гц (рис. 2б).

В целом, графики вертикальных компонент в высоких частотах (1-10 Гц) суточно и в течение года находятся примерно на одном уровне (рис. 2a, 2б).

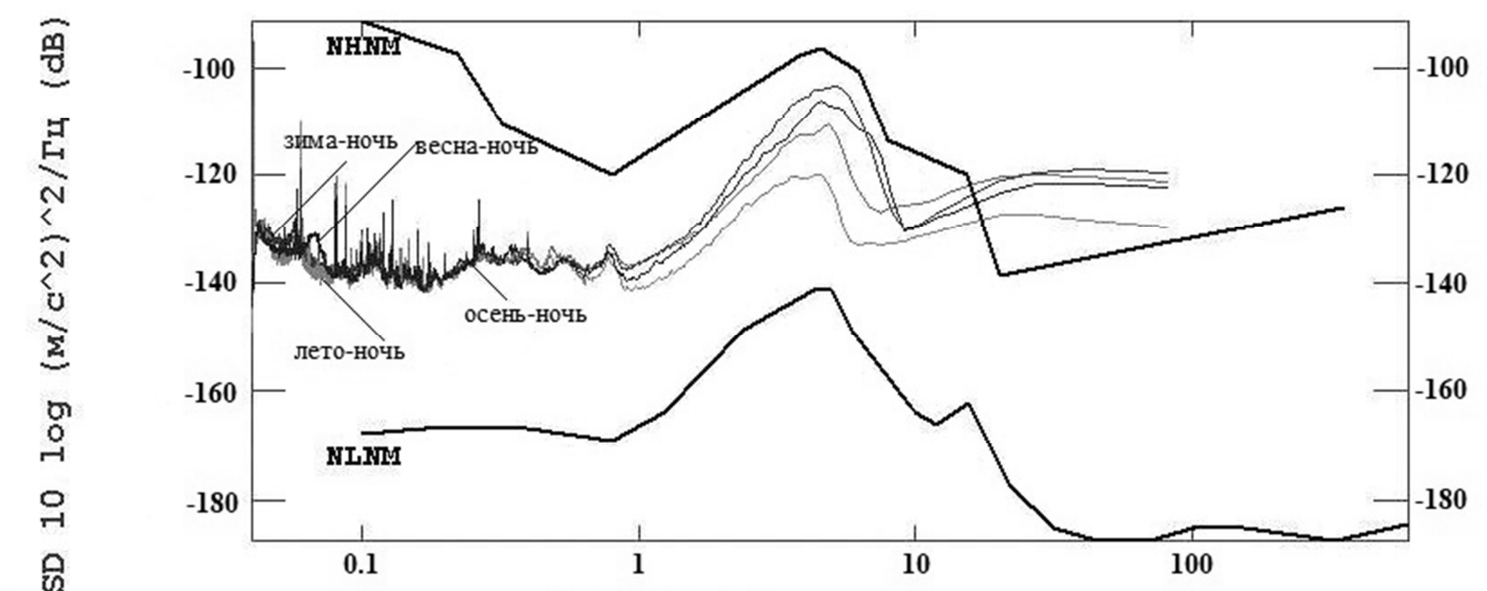

a)

Период (c)
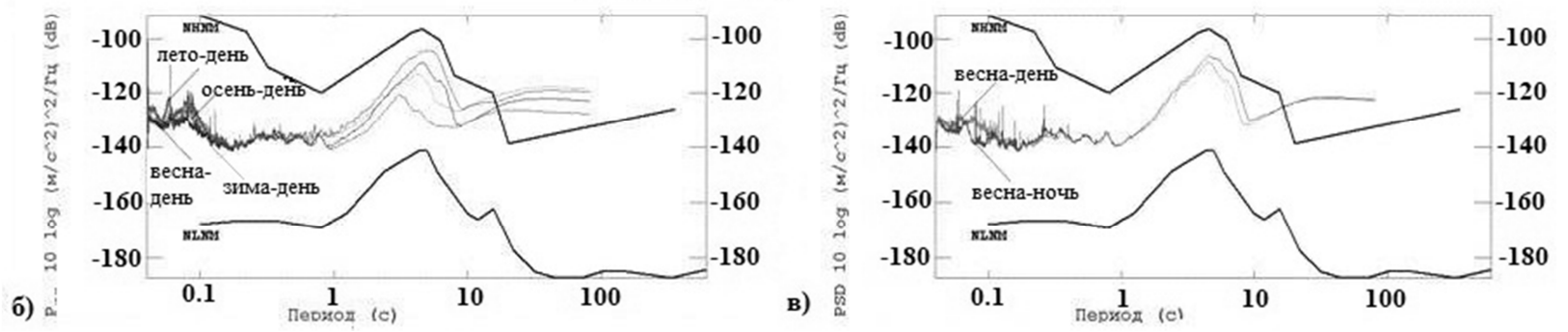

Puc. 2. График СПМ шума сейсмической станции «Костомукша» KOS6: $a$ - все сезоны (ночное время), $\sigma$ - все сезоны (дневное время), 6 - весенний сезон (дневное и ночное время). 
В низких частотах (от 0,5 Гц) графики в течение года по уровню шума различны, однако, наблюдается одинаковая последовательность в распределение сезонных графиков СПМ шума и днём, и ночью: самое шумное время года - зима, далее весна, осень и лето. Суточные же вариации уровня шума в сезоне минимальны (рис. 2в).

\section{Сейсмическая станщия «Питкяранта» РITK}

Анализируя графики СПМ шума по временам года от 10 Гц и выше, можно условно разделить их на 2 группы: зима-весна и лето-осень. Разница в уровне шума в этом частотном промежутке достигает 10 Дб. Самое шумное время года в высокочастотной области графика - зима, далее весна, а осень и лето находятся примерно на одном уровне (рис. 3a). В диапазоне 3 10 Гц в течение года и суток уровень шума постоянен и графики мало различны, а после 3 Гц графики снова можно разделить на 2 категории, где разница в уровне шума составляет уже 2-4 Дб. Начиная с 1,56 с, появляется чёткое сезонное распределение графиков.

В течение одного сезона наблюдаются практически нулевые суточные вариации шума (рис. 3б), за исключением весны (рис. 3в). Особенность весенней кривой - преобладание шума в ночное время на 2 Дб в области высоких частот (до 1 Гц). Далее оба графика находятся практически на одном уровне, и лишь в низких частотах $(0,3$ Гц) уровень шума ночью становится ниже.

Рассматривая длиннопериодную часть спектров (с 0,5 c), отмечается аналогичное поведение графиков, описанное выше (сейсмическая станция KOS6). Исключение составляет одинаковый уровень шума летом и осенью после 0,1 Гц.

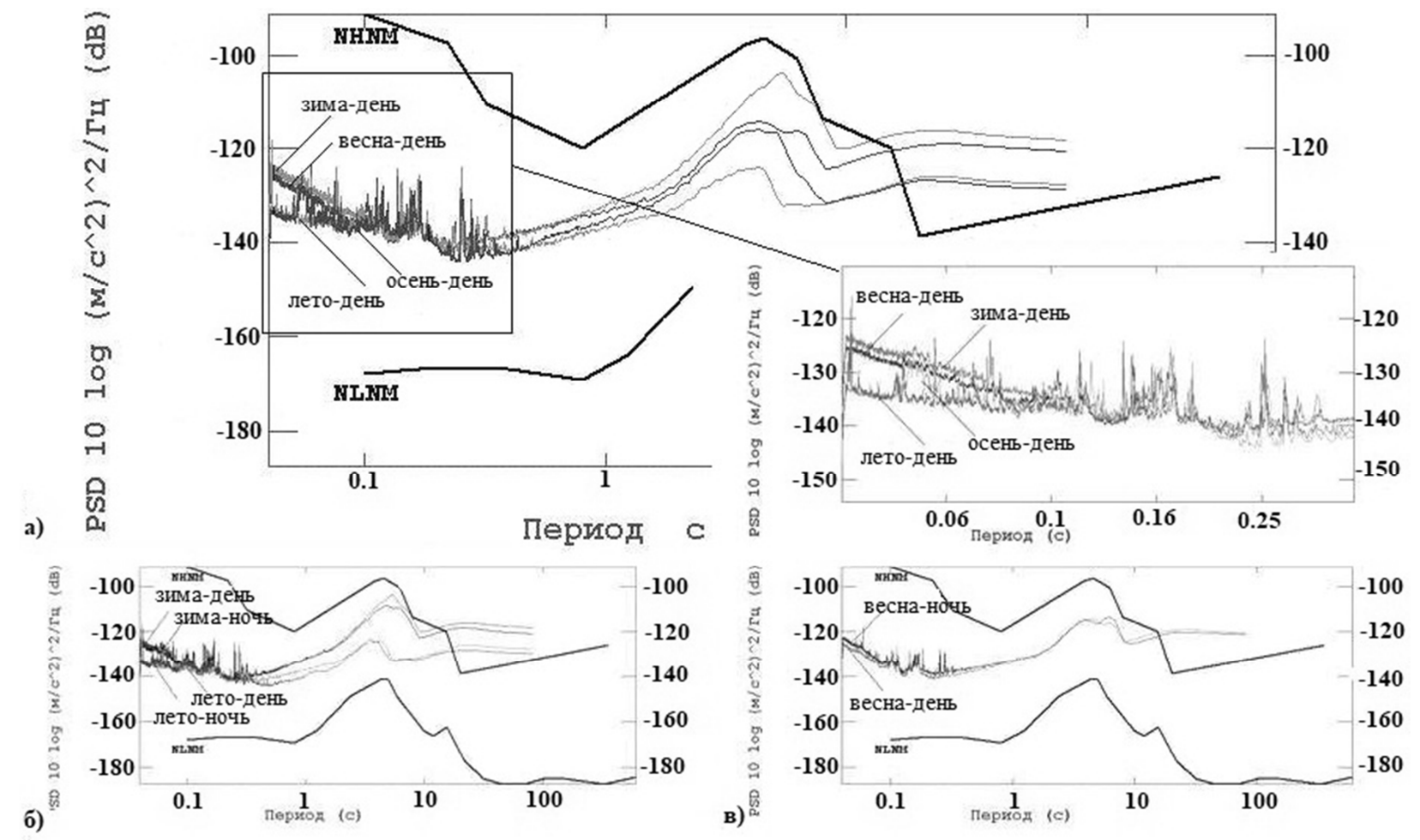

Puc. 3. График СПМ шума сейсмической станции «Питкяранта» РІTК: а - все сезоны (дневное время), б - зимний и летний сезоны (дневное и ночное время), в - весенний сезон (дневное и ночное время).

Сейсмическая станциия «Петрозаводск» PTRZ

Анализ уровня шума в районе расположения сейсмической станции PTRZ описан в [1], где приведены исследования данных по двум типам аппаратуры. Однако по сезонам года такая работа ещё не производилась.

Сезонные изменения уровня шума вертикальных компонент в ночное время минимальны, в отличие от изменений днем. Это подтверждается сопоставлением дневных графиков СПМ шума осенью (самая низкошумная дневная кривой) и летом (самая высокошумная дневная кривая), где разница между кривыми составляет до 6 Дб (промежуток частот 10-16 Гц). Это связано с возрастанием антропогенной нагрузки: на территории Ботанического сада, где установлена станция: летом возрастает популярность посещения данного объекта туристами, а также работает тяжёлая техника.

Аналогия сезонного распределения графиков по уровню шума в низких частотах сохраняется и для станции PTRZ, только ночью она отчётливо наблюдается уже на частотах менее 0,08 Гц. До этой частоты, ночью, в промежутке 1-0,1 Гц, все графики примерно на одном уровне, с 0,1 Гц до 0,08 Гц весна - более шумное время года (рис. $4 \mathrm{a}, 46)$. 


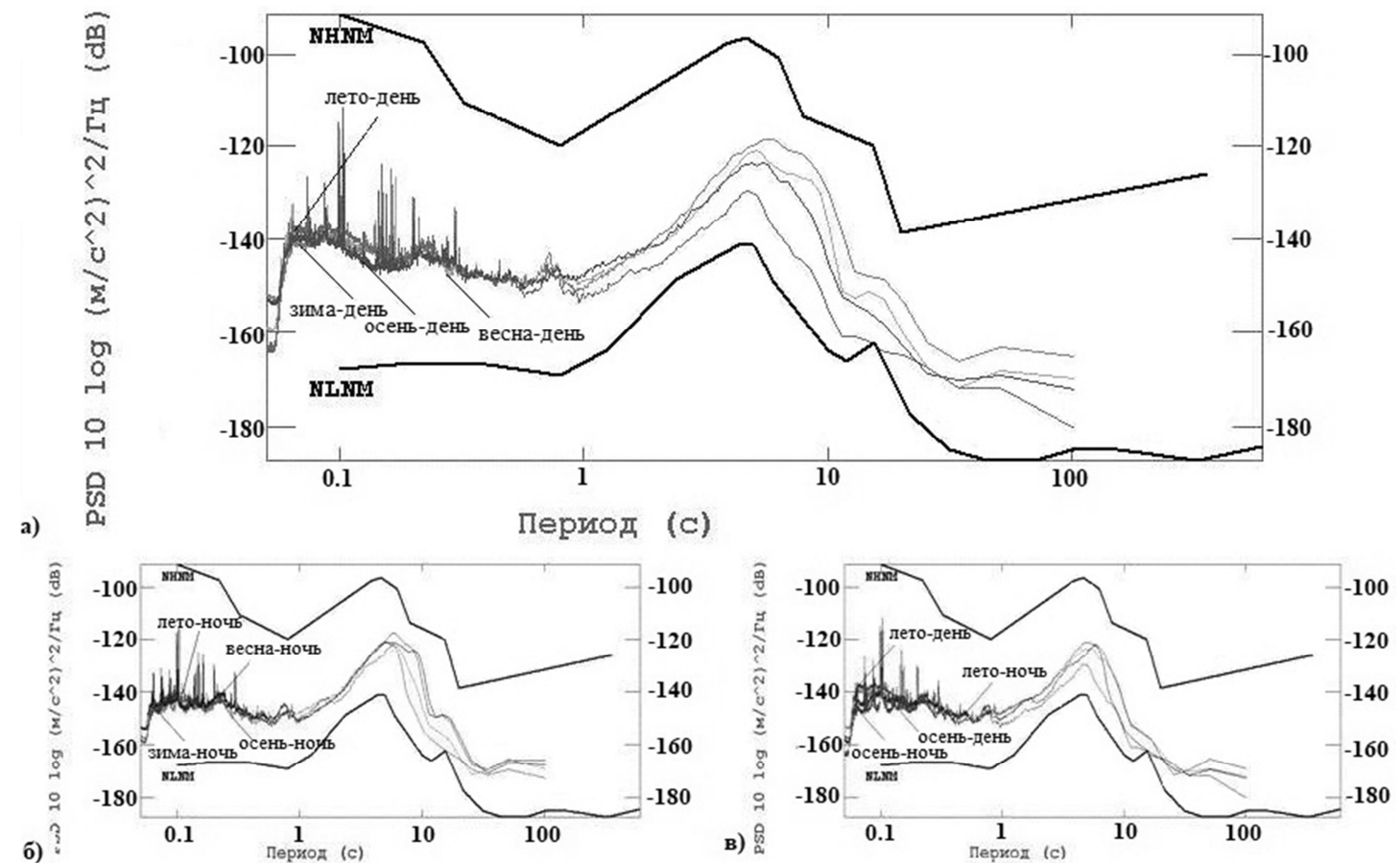

Puc. 4. График СПМ шума сейсмической станции «Петрозаводск» PTRZ: а - все сезоны (дневное время, б - все сезоны (ночное время), в - летний и осенний сезоны (дневное и ночное время).

Сейсмическая станция «Паанаярви» PAAN

Самый высокий уровень шума среди станций Карельской сейсмологической сети наблюдается в месте установки станции «Паанаярви» (рис. 5а). По полученным за год в дневное время графикам наблюдается превышение верхнеуровневой модельной кривой Пе- терсона кривыми обеих горизонтальных компонент сейсмической станции PAAN в высокочастотной области (2-3 Гц) - частотный диапазон обнаружения локальных и региональных событий (рис. 5б). Это связано с установкой станции на фундаменте здания с высокой антропогенной нагрузкой.

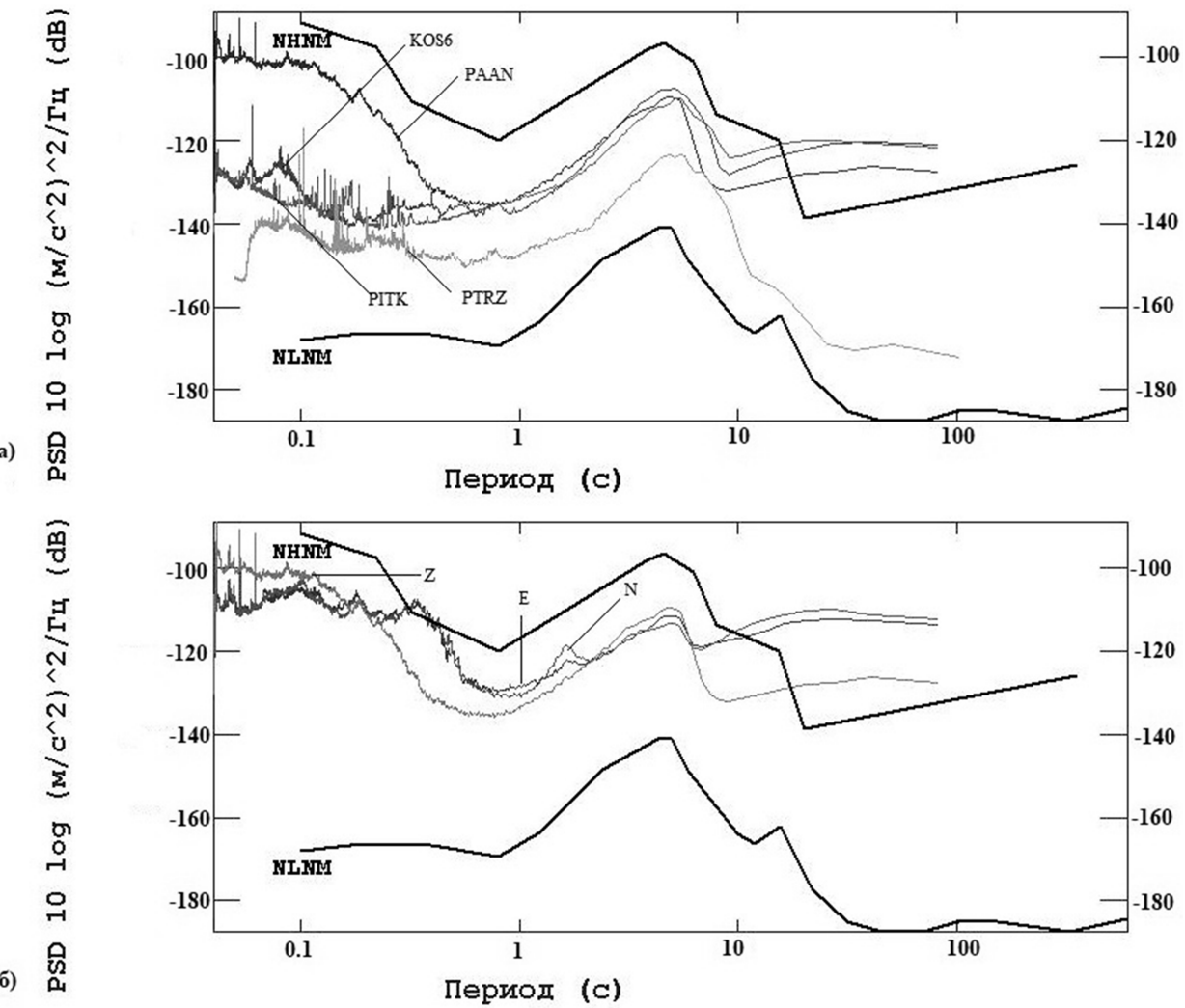

Puc. 5. СПМ шума вертикальных компонент сейсмических станций Карельской сейсмологической сети: а - годовые графики всех станций, б - графики компонент станции «Паанаярви» PAAN. 


\section{Обсуждение результатов}

Возможности регистрации сейсмических событий станциями Карельской сейсмологической сети исследованы благодаря построению СПМ шума и их анализа относительно модельных кривых Петерсона. Изучение вариаций кривых в зависимости от времени года и суток позволило сделать следующие выводы для каждой станции:

\section{KOS6}

Высокие частоты:

- в течение года уровень шума малоизменчив - стабильность регистрации локальных и региональных событий.

- в течение суток: днём снижается надёжность регистрации событий (промежуток частот 10-16 Гц) из-за возрастания уровня шума от 1 до 10-15 ДБ (12-11 Гц)

\section{PITK}

Высокие частоты:

- в течение года в выделении событий от 10 Гц и выше зимой и весной возникают трудности (увеличения уровня шума до 10 Дб). Увеличение шума наблюдается и осенью (до 5 Дб) в пределах 12-14 Гц. Следовательно, летом выше вероятность регистрации событий высоких частот. Выделение событий в частотах 3-10 Гц не зависит от сезона года и является стабильным.

- суточные изменения шума минимальны и значительно не влияют на регистрацию.

\section{PTRZ}

Высокие частоты:

- Сезонность практически не оказывает сильного влияния на регистрацию событий

- В течение суток: в связи с высокой антропогенной нагрузкой днём уровень шума возрастает до 7 Дб, что затрудняет выделение сейсмических событий.

Низкие частоты (KOS6, PITK, PTRZ): уровень шума в течение года сильно варьирует, обнаружение телесейсмических событий, сравнивая с летом, зимой и весной значительно усложняется.

\section{PAAN}

До переустановки станции нет смысла проводить анализ СПМ шума в течение года.

Оценивая уровень шума Карельских сейсмических станций (рис. 5a), самый низкий наблюдается на станции PTRZ, затем по возрастанию следуют станции PITK и KOS6. И самой шумной является сейсмостанция PAAN, требующая в дальнейшем переустановки

\section{Заключение}

1. Все компоненты сейсмических станций Карелии расположены в пределах модельных кривых Петерсона высокого и низкого уровня шума, за исключением горизонтальных компонент станции «Паанаярви». Таким образом, характеристики остальных станций (PITK, KOS6, PTRZ) соответствуют поставленным задачам сейсмического контроля территории
Карелии.

2. На графиках спектров каждой станции отмечается наличие ярко выраженных пиков, связанных с квазимонохроматическими составляющими шума, которые могут иметь как техногенную, так и естественную природу [13]. Данные пики присутствуют на спектрах постоянно, и лишь из-за увеличения уровня шума в дневное время часть пиков может оказаться невидимыми.

3. Графики всех трёх компонент, полученных по данным сейсмических станций, которые укомплектованы сейсмическими датчиками Guralp CMG-6TD, пересекают модельную кривую NHNM после 15 с, что связано, скорее всего, с конструктивным недостатком аппаратуры, который абсолютно не влияет на регистрацию локальных и региональных событий.

Авторы выражают благодарность за всестороннюю поддержку при проведении исследований сотрудников КоФ ФИЦ ЕГС РАН А. В. Фёдорова и В. Э. Асминга, за иенные советы и замечания Н. В. Шарова, В. Ю. Бурмина.

\section{ЛИТЕРАТУРА}

1. Климовский, А. В. Динамические характеристики сейсмической станции Петрозаводск / А. В. Климовский, В. А. Мещерякова, А. А. Лебедев // Труды КарНЦ РАН. - №2. Петрозаводск, 2016. - С. 105-111.

2. Адушкин, В. В. Физические поля в приповерхностной геофизике / В. В. Адушкин, А. А. Спивак. - М.: ГЕОС, 2014. $-358 \mathrm{c}$.

3. Статистическая модель коррелированного сейсмического шума / А. В. Анищенко [и др.] // Вестник Воронеж. гос. ун-та. Сер. Геология. - № 2. - 2011. - С. 201-208.

4. Слабунов, А. И. Геология и геодинамика архейских подвижных поясов (на примере Беломорской провинции Фенноскандинавского щита) / А. И. Слабунов. - Петрозаводск: изд. КарНЦ РАН, 2008. - 296 с.

5. Шаров, Н. В. Глубинное строение и сейсмичность Карельского региона и его обрамления / Н. В. Шаров. Петрозаводск: изд. КарНЦ РАН, 2004. - 353 с.

6. Онежская палеопротерозойская структура (геология, тектоника, глубинное строение и минерагения) / Отв. Ред. Л. В. Глушанин, Н. В. Шаров, В. В. Щипцов. - Петрозаводск: КарНЦ РАН, 2011. - $431 \mathrm{c.}$

7. Светов, А. П. Геология докембрийского кристаллического фундамента Юго-Западной Карелии в концепции природного парка «Ладожские шхеры» / А. П. Светов // Природные парки в территориальной организации Южной Карелии: сб. научн. трудов. - Спб.: Изд-во Русск. Географич. О-ва, 1995. - С. 9-20.

8. Геологическая карта СССР. Карельская серия. Лист Q36-XIX, XX / В.А Попова и др. - М., 1976 // База данныХ государственных геологических карт ВСЕГЕИ. - Режим доступа: http://wms.vsegei.ru/rasters/wms? (дата обращения: 24.04.17)

9. Геологическая карта дочетвертичных отложений СССР. Карельская серия. Лист Q-36-XXXI, XXXII. М-б 1:200000./ Е. М Михайлюк, В. С. Алексеева, Ред. В.Я. Горьковец. - М.: ПГО «Севзапгеология», 1986 // База данных Государственных геологических карт ВСЕГЕИ. - Режим доступа: http://wms.vsegei.ru/rasters/wms? (дата обращения: 24.04.17) 
10. McNamara, D. E. Ambient Noise Levels in the Continental UnitedStates, / D. E. McNamara, R. P. Buland // Bull. Seism. Soc. Am. - V.94 - No 4. - 2004. -1517-1527.

11. Peterson, J. Observation and modeling of seismic background noise / J. Peterson // Open-File Rept. 93-322. - U. S. Geol. Surv., 1993. - P. 1-95.

12. Фёдоров, А. В. Изучение характеристик сейсмического шума сети станций, используемых в рутинной обработке

Институт геологии - обособленное подразделение Федерального государственного бюджетного учреждения науки Федерального исследовательского центра «Карельский научный иентр Российской академии наук»,

2. Петрозаводск

Мещерякова Вера Александровна, младший научный сотрудник

E-mail: meshcher_va@krc.karelia.ru; Тел.: +7 (8142) 783471

Герасимова Анна Александровна, старший лаборант-

исследователь

E-mail: gerasimova@krc.karelia.ru; Тел.: +7(8142) 783471
Кольским филиалом ГС РАН / А. В. Фёдоров, В. Э. Асминг // Современные методы обработки и интерпретации сейсмологических данных: материалы 8-й Международной сейсмологической школы. - Обнинск, 2013. - С. 322-326.

13. Спивак, $A$. А. Исследование микросейсмического фона с целью определения активных тектонических структур и геодинамических характеристик среды / А. А Спивак, С. Б. Кишкина // Физика Земли. -2004 - № 7. - С. 35-49.

Institute of Geology of the Karelian Research Centre of the Russian Academy of Sciences, Petrozavodsk

Meshcheryakova V. A., junior researcher

E-mail: meshcher_va@krc.karelia.ru

Tel.: +7 (8142) 783471

Gerasimova A. A., senior laboratory researcher

E-mail: gerasimova@krc.karelia.ru

Tel.: +7 (8142) 783471 